\title{
The influence of differing hunting practices on the relative abundance of mammals in two rainforest areas of the Western Ghats, India
}

\author{
H.N. Kumara and Mewa Singh
}

\begin{abstract}
We assessed the distribution and relative abundance of mammals in two rainforest areas, Brahmagiri-Makut and Sirsi-Honnavara, of the Western Ghats, southern India, from November 2001 to April 2002. Both direct (daytime and night-time wildlife sightings through 'recky' walks) and indirect (wildlife signs and local information) methods were employed. A total of 34-35 species, of which we recorded 31-32, are known from the two areas; 14 are in one of the IUCN Red List threatened categories and six are endemic to India. Ecological factors account for the distribution and relative abundance of only three species (Nilgiri langur Semnopithecus johnii, lion-tailed macaque Macaca silenus and Asiatic elephant Elephas maximus). Ten other large species of mammals were more common in SirsiHonnavara than in Brahmagiri-Makut, whereas most of nine smaller species were generally more common in Brahmagiri-Makut. These differences can be attributed
\end{abstract}

to different hunting practices rather than to ecological or biogeographical factors. In Brahmagiri-Makut the mainly daytime hunting using guns has the greatest impact on large diurnal mammals, whereas in SirsiHonnavara the mostly night-time hunting with traps, and avoidance of primates, has a greater effect on small nocturnal mammals. Brahmagiri-Makut is one of the few areas in the Western Ghats where all of the primate species of southern India can still be found, but the area does not receive any official protection. In Sirsi-Honnavara encroachment of agriculture is a regular practice, and the remaining forests exist only as a network of narrow strips.

Keywords Hunting practices, India, langur, mammals, rainforest, Western Ghats.

This paper contains supplementary material that can only be found online at http:/ /journals.cambridge.org

\section{Introduction}

Increasing human populations, especially in tropical countries, have caused loss of potential habitats and lead to species extinctions (Pimm \& Raven, 2000) and uneven and clumped species' distributions (Myers et al., 2000). Anthropogenic processes such as hunting have also resulted in the decline of many wildlife species (Diamond, 1989; Madhusudan \& Karanth, 2002). One area that has been particularly affected by human population growth and hunting is the Western Ghats mountain range, which runs parallel to the west coast of south India, passing through six states, and harbours a great variety of animal species; it has been recognized as a hot spot of biodiversity (Myers et al., 2000). The Western Ghats also have the highest human population density of all hotspots (Cincotta et al., 2000).

Ramesh (2001) classified the ecological zones of the Western Ghats as Wet Evergreen Forests, Dry Evergreen

H.N. Kumara and Mewa Singh (Corresponding author) Biopsychology Laboratory, University of Mysore, Mysore-570006, India

E-mail mewasingh@sancharnet.in

Received 5 March 2003. Revision requested 1 September 2003. Accepted 19 January 2004
Climax Forests and Deciduous Climax Forests. Most of the ecological studies in the Western Ghats have described the ecology, distribution and behaviour of individual species, but only a few studies have dealt with broader issues. Madhusudan \& Karanth (2002) discussed local hunting of large mammals in Kudremukh and Nagarahole, two protected areas in the state of Karnataka. Other studies have included habitat fragmentation and its impact on small mammals and primates (Kumar et al., 1995; Umapathy \& Kumar, 2000), the lion-tailed macaque Macaca silenus (Singh et al., 2002), small carnivores (Rai \& Kumar, 1993; Ashraf et al., 1995; Yoganand \& Kumar, 1995; Mudappa, 2001), the flying squirrels Petaurista petaurista and Petinomys fuscocapillus (Kurup, 1989; Ashraf et al., 1993), and mammals of a wildlife sanctuary in Tamil Nadu (Kumar et al., 2002). Two earlier studies on distribution of mammals in the state of Karnataka (Prasad et al., 1975; Karanth, 1986) were based largely on secondary information.

Of the total $78,387 \mathrm{~km}^{2}$ of the Western Ghats, $17,613 \mathrm{~km}^{2}$ (20\%) falls within protected areas (Johnsingh, 1986). Because most studies have been conducted in and around these protected areas, little information is available on mammalian ecology in other areas. In the 
present study two regions of rainforest of the Western Ghats where official protection status of the forest and the culture and lifestyle of people differ were selected. We describe the diversity, distribution and relative abundance of mammals in these two areas, and evaluate the impact of different hunting practices. Our focus is on larger mammals in particular because their size and visibility makes them more susceptible to human pressures (Robinson \& Redford, 1986; Arita et al., 1990) and they are more likely to lead to human-animal conflict.

\section{Study area}

The study was carried out in Brahmagiri-Makut in southern Karnataka and Sirsi-Honnavara in northern Karnataka (Fig. 1, Table 1). In Brahmagiri-Makut the habitats are shola grasslands (narrow patches within the rainforest) at higher altitudes and evergreen and semievergreen forests at medium and lower altitudes. The distribution of Cullenia exarillata, a dominant tree in the wet evergreen forests at medium elevations throughout

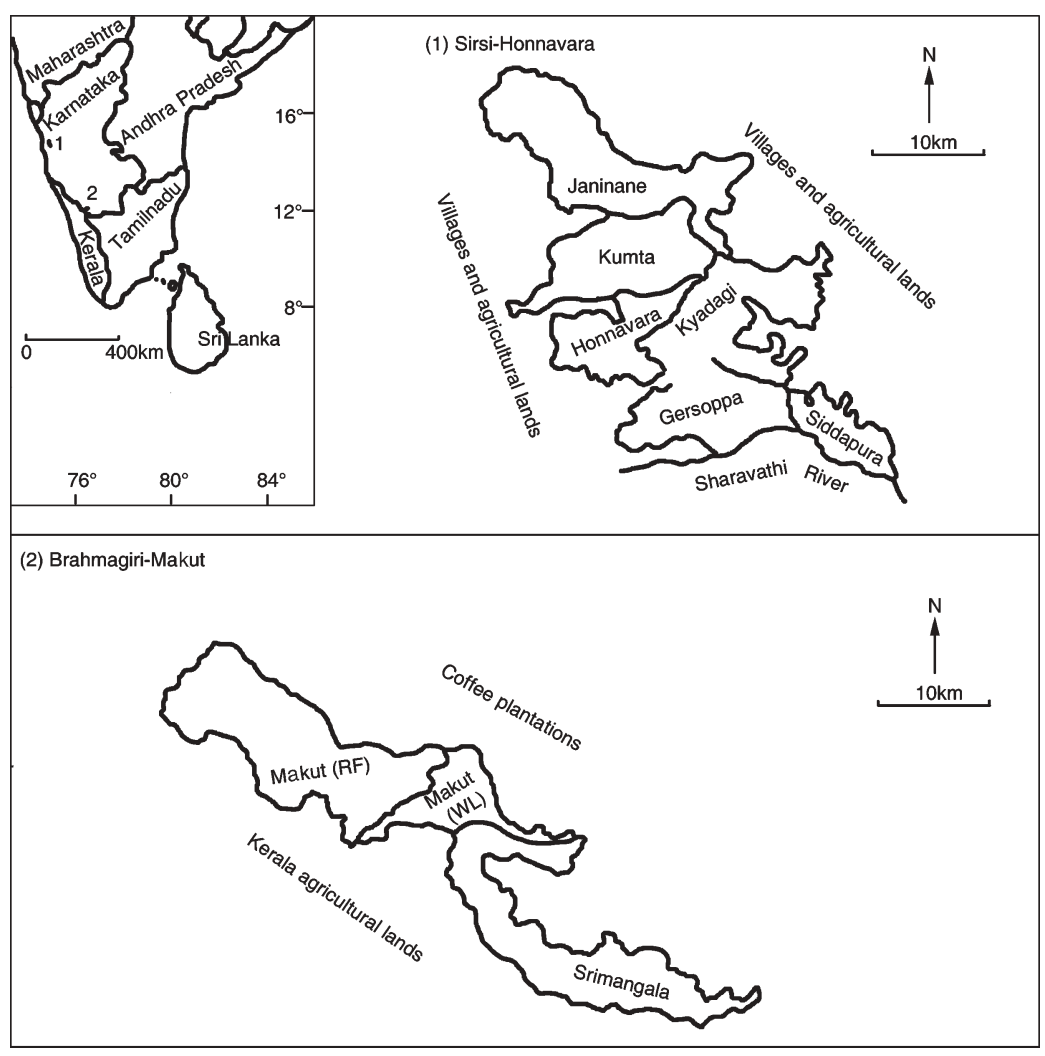

Fig. 1 Southern India, indicating the location of the two study areas of Sirsi-Honnavara (1) and Brahmagiri-Makut (2) in the state of Karnataka; the detail of each area indicates the location of the Forest and Wildlife Ranges (see Table 1).

Table 1 Summary of geographical, climate and administrative features of the two study areas of Brahmagiri-Makut and Sirsi-Honnavara (see Fig. 1).

\begin{tabular}{lcc}
\hline & Brahmagiri-Makut & Sirsi-Honnavara \\
\hline Area $\left(\mathrm{km}^{2}\right)$ & 306 & 200 \\
Altitude range $(\mathrm{m})$ & $60-1,600$ & $200-800$ \\
Temperature range $\left({ }^{\circ} \mathrm{C}\right)$ & $5-32$ & $15-35$ \\
Total annual rainfall $(\mathrm{mm})$ & Up to 6,000 & Up to 5,000 \\
Vegetation types & Mesua ferrea - Palaquim ellipticum & Persea macrantha-Diospyros spp.- Holigarna spp. \\
Names of Administrative Ranges & Srimangala \& Makut Forest Ranges, & Sirsi Divison: Janmane, Kyadagi \& Siddapura \\
& Makut Wildlife Range & Forest Ranges. Honnavara Division: \\
& & Kumta, Honnavara \& Gersoppa Forest Ranges ${ }^{2}$ \\
\hline
\end{tabular}

${ }^{1}$ Pascal (1988).

${ }^{2} \mathrm{~A}$ Forest Range is an area of $50-100 \mathrm{~km}^{2}$ administered by a Forest Range Officer within a larger area such as a Forest Division.

${ }^{3} \mathrm{~A}$ Wildlife Range is an area of forest reserved for wildlife and within which no forestry activities are permitted. 
the Western Ghats (Pascal, 1988; Ramesh, 2001) ends just to the south of Brahmagiri-Makut. Although there is no human habitation within the forests of BrahmagiriMakut, the forest boundary is densely populated. Eleven communities, or castes, live on the eastern border. More than $80 \%$ of the population are Kodavas (a land-owning warrior community) and $5-7 \%$ are forest-dwelling tribes. Christian and Muslim communities dominate the western border. The people frequently come into conflict with authorities over resource use (Machaiah, pers. comm.).

The forest type of Sirsi-Honnavara constitutes the northern limit of the evergreen forests of the plains and low elevations of south India (Pascal, 1988). Villages are scattered throughout these forests, and to document patterns of land use we selected seven villages from the Kyadagi Forest Range. These villages were Suthlamane, Talkeri, Nirgod, Kodigadde, Dhanmavu, Hukkali, and Kaunsale, with a total area of 4,857 ha. The agricultural land was 345 ha and the forest area was 4,224 ha, amounting to $7 \%$ and $87 \%$ of the total area respectively. At least 596 houses with a population of $c$. 2,047 were scattered throughout the forest. Approximately $82 \%$ of the total population of the region belonged to three communities, or castes; the Nayaka, Vokkaliga Gowda and Harijana. They were the major hunting communities. Muslims, Christians and some nomadic tribes such as Hakki Koramaru and Beduvavaru also hunt in the region.

\section{Methods}

The study was conducted in Brahmagiri-Makut from November 2001 to January 2002, and in Sirsi-Honnavara during February-April 2002. We made 'recky walks' (Walsh \& White, 2000) at $0.8 \mathrm{~km} \mathrm{~h}^{-1}$ on both pre-existing trails and new routes, with a pedometer used to record distance walked. During 41 and 44 days of walks in Brahmagiri-Makut and Sirsi-Honnavara the average distance covered per day was $6.4 \mathrm{~km}( \pm$ SD 2.5) and $4.5 \mathrm{~km}$ ( \pm SD 2.2), respectively. All mammal species sighted were noted, and when necessary sufficient time was spent to determine group size. The number of traps and hunters encountered was noted. Because both study areas contain rainforest and we anticipated that similar mammal species would be encountered in both areas, we assumed that differences in visibility or detectability between the two areas would not bias observations significantly. The encounter rate (i.e. animals $\mathrm{km}^{-1}$ ) was used as the relative abundance of a species. Night-time walks were also made in the same areas, using spotlights, and the relative abundance of species sighted was estimated as the number of individuals sighted per spotlight-hour (Kemper, 1988). The total distances walked during daytime were 238 and $198 \mathrm{~km}$, and the spotlight hours during night-time walks were 27 and 46 in Brahmagiri-Makut and Sirsi-Honnavara, respectively. Additional information on the presence and absence of mammal species was gathered from forest staff, local inhabitants, footprints, faecal deposits, calls, kills, foraging and roosting signs. A list of mammal species in the two areas was compiled from our survey data, from earlier published records (Prater, 1993), and local information.

Interviews (Appendix 1) were employed to record hunting technique, hunting intensity, hunters' prey choice, and influence of socio-cultural factors on hunting practices. Multiple responses were permitted to a single question (Madhusudan \& Karanth, 2002). Because most people avoided filling the questionnaire, we talked with them to obtain the required information, and later filled in the questionnaire. We interviewed 42 forest personnel and nine local informants in Brahmagiri-Makut, and 32 hunters in Sirsi-Honnavara. Not all items in the questionnaire could be filled for all individuals, as some information was not divulged. Information on number of guns in the villages around Brahmagiri-Makut was obtained from the local Police Department and Karnataka Forest Department, and in Sirsi-Honnavara from interviews. Because the data collected through interviews was incomplete, it could not be presented in a systematic form or analysed statistically, and we therefore present it in summary form. In Sirsi-Honnavara, Karnataka Forest Department and Karnataka Revenue Department provided information on land use patterns, forest encroachment for agricultural purposes, and village populations.

\section{Results}

\section{Mammal species}

Of the 34-35 species listed known from the two areas (Appendix 2), 31-32 were recorded during this study (only local information is available for the two species of otter that potentially occur in the area, and we are unable to determine whether one or both of the species are present). On the Red List (IUCN, 2003) 14 of these 35 species are in one of the threatened categories (one Critically Endangered, three Endangered, 10 Vulnerable), three are categorized as Lower Risk: near threatened and one as Data Deficient. Six of the recorded species are endemic to India (Appendix 2). Although we did not record the occurrence of the rusty spotted cat Felis rubiginosa, fishing cat Felis viverrina and Malabar civet Viverricula megaspila, they were previously known from both areas (Prater, 1993; Rai \& Kumar, 1993; Yogananda \& Kumar, 1995). Leopard cat Prionailurus bengalensis, Travancore 
flying squirrel Petinomys fuscocapillus and Nilgiri marten Martes gwatkinsi were recorded only in BrahmagiriMakut. Lion-tailed macaque Macaca silenus was present in all Forest Ranges except Janmane and Kumta in SirsiHonnavara; only a lone male has been sighted in recent years in Brahmagiri-Makut. Nilgiri langur Semnopithecus johnii was found only in Srimangala in BrahmagiriMakut. Tiger Panthera tigris, leopard P. pardus, dhole Cuon alpinus and jackal Canis aureus were the predominant larger carnivores found in the study areas. Sloth bear Melursus ursinus signs were not observed in either Makut Forest Range or Makut Wildlife Range but were recorded in other Ranges. Elephant Elephas maximus was absent from Sirsi-Honnavara but occurred in all Ranges of Brahmagiri-Makut. The other mammals listed in Appendix 2 were found in all Forest Ranges of both study areas.

\section{Relative abundance of mammals}

The encounter rates of most of the 10 larger species of mammals, sighted during the day, were higher in SirsiHonnavara than in Brahmagiri-Makut, whereas most of the nine smaller species of mammals, spotted during the night, were generally more common in BrahmagiriMakut. The overall daytime encounter rate of the five arboreal mammal species seen in Brahmagiri-Makut and Sirsi-Honnavara was 2.22 and $18.52 \mathrm{~km}^{-1}$, respectively (Table 2$)$, and significantly higher $(z=27.93, \mathrm{P}=0.01)$ in Sirsi-Honnavara. The overall daytime encounter rate of the five herbivorous terrestrial mammal species seen was $0.187 \mathrm{~km}^{-1}$ in Sirsi-Honnavara, which was significantly higher $(z=3.02, \mathrm{P}=0.01)$ than the rate of $0.088 \mathrm{~km}^{-1}$ in Brahmagiri-Makut (Table 2). A relatively low number of four small carnivorous mammal species were seen during night-time walks (Table 3), and the number

Table 2 Number and number per km of arboreal and terrestrial herbivorous mammals seen during daytime walks in Brahmagiri-Makut $(238 \mathrm{~km})$ and Sirsi-Honnavara $(198 \mathrm{~km})$.

\begin{tabular}{|c|c|c|c|c|}
\hline \multirow[b]{2}{*}{ Species } & \multicolumn{2}{|c|}{ Brahmagiri-Makut } & \multicolumn{2}{|c|}{ Sirsi-Honnavara } \\
\hline & No. & No. $\mathrm{km}^{-1}$ & No. & No. $\mathrm{km}^{-1}$ \\
\hline \multicolumn{5}{|l|}{ Arboreal } \\
\hline Hanuman langur Semnopithecus entellus & 137 & 0.576 & 1,784 & 9.010 \\
\hline Nilgiri langur Semnopithecus johnii & 39 & 0.164 & 0 & \\
\hline Bonnet macaque Macavca radiata & 285 & 1.197 & 1,045 & 5.278 \\
\hline Lion-tailed macaque Macaca silenus & 18 & 0.076 & 790 & 3.990 \\
\hline Indian giant squirrel Ratufa indica & 49 & 0.206 & 48 & 0.242 \\
\hline Total & 528 & 2.218 & 3,667 & 18.520 \\
\hline \multicolumn{5}{|l|}{ Terrestrial herbivores } \\
\hline Sambar Cervus unicolor & 11 & 0.046 & 6 & 0.030 \\
\hline Wild pig Sus scrofa & 7 & 0.029 & 24 & 0.121 \\
\hline Indian spotted chevrotain Tragulus meminna & 1 & 0.004 & 3 & 0.015 \\
\hline Indian muntjac Muntiacus muntjak & 1 & 0.004 & 4 & 0.020 \\
\hline Gaur Bos frontalis & 1 & 0.004 & 0 & \\
\hline Total & 21 & 0.088 & 37 & 0.186 \\
\hline
\end{tabular}

Table 3 Number and number per spotlight hour of small carnivorous and other small mammals encountered during night-time walks in Brahmagiri-Makut (27 spotlight hours) and Sirsi-Honnavara (46 spotlight hours).

\begin{tabular}{|c|c|c|c|c|}
\hline \multirow[b]{2}{*}{ Species } & \multicolumn{2}{|c|}{ Brahmagiri-Makut } & \multicolumn{2}{|c|}{ Sirsi-Honnavara } \\
\hline & No. & No. $h^{-1}$ & No. & No. $h^{-1}$ \\
\hline \multicolumn{5}{|l|}{ Small carnivores } \\
\hline Brown palm civet Paradoxurus jerdoni & 4 & 0.148 & 4 & 0.087 \\
\hline Asian palm civet Paradoxurus hermaphroditus & 2 & 0.074 & 2 & 0.043 \\
\hline Small Indian civet Viverricula indica & 1 & 0.037 & 0 & \\
\hline Leopard cat Prionailurus bengalensis & 1 & 0.037 & 0 & \\
\hline Total & 8 & 0.296 & 6 & 0.130 \\
\hline \multicolumn{5}{|l|}{ Other small mammals } \\
\hline Travancore flying squirrel Petinomys fuscocapillus & 5 & 0.185 & 0 & \\
\hline Giant flying squirrel Petaurista petaurista & 15 & 0.555 & 30 & 0.652 \\
\hline Slender loris Loris tardigradus & 11 & 0.407 & 15 & 0.326 \\
\hline Indian spotted chevrotain Tragulus meminna & 6 & 0.222 & 0 & \\
\hline Indian crested porcupine Hystrix indica & 1 & 0.037 & 1 & 0.022 \\
\hline Total & 38 & 1.407 & 46 & 1.000 \\
\hline
\end{tabular}


sighted per spotlight hour was not significantly different between the two areas $(z=1.73, \mathrm{P}>0.05)$. However, the number of five other species of small mammals seen per spotlight hour in Brahmagiri-Makut (1.4 spotlight $\mathrm{h}^{-1}$ ) was significantly higher $(z=3.91, \mathrm{P}=0.01)$ than in SirsiHonnavara (1.0 spotlight $\mathrm{h}^{-1}$ ) (Table 3$)$. Evidence for the other 13 species of mammals (Appendix 2) came from indirect signs.

\section{Hunting practices}

Most families on the eastern and western borders of Brahmagiri-Makut owned licenced and unlicenced guns, respectively, which were used for hunting (Table 4). Large mammals were generally hunted in preference to small mammals. Hunting was for both illegal commercial purposes and personal consumption. On the western border, because of beliefs in medicine based on the use of animal parts, especially primates, a lion-tailed macaque fetched 4,000-5,000 rupees (US \$90-100), a Nilgiri langur c. 3,000 rupees and a Hanuman langur c. 200 rupees per $\mathrm{kg}$. There were no religious inhibitions against the hunting of any species, which mainly took place during the daytime when larger mammals could be easily seen.

In Sirsi-Honnavara, in addition to the use of guns, various traps designed for certain species were used for hunting (Table 4). We saw a total of 37 traps (0.18 traps $\mathrm{km}^{-1}$ ). Most animals hunted or trapped were small mammals. Hunting of primates was mostly avoided, for religious reasons (as a monkey is accorded a godlike status), except by Beduvavaru, a nomadic tribe that occasionally visit the forest. Farmers of the Vokkaliga Gowda caste did not hunt flying squirrels, and the Hakki Koramaru tribe caught mainly small terrestrial mammals.

\section{Discussion}

The southerly Brahmagiri-Makut is a conspicuous ecotone in the Western Ghats because it is at the southernmost range of forests dominated by Cullenia, whereas the northerly Sirsi-Honnavara is at the northern edge of climax tropical rainforests (Pascal, 1988). The northernmost range of the Nilgiri langur, which is widespread in the southern areas of the Western Ghats, where it is sympatric with lion-tailed macaque and occasionally with bonnet macaque (Singh et al., 1997; Ramachandran \& Joseph, 2001), is at the Brahmagiri-Makut ecotone. The northernmost range of the lion-tailed macaque is at SirsiHonnavara, coincident with the northernmost range of dipterocarpous forests.

Two species of flying squirrels have been reported to occur in the Western Ghats. Whereas the large brown flying squirrel Petaurista petaurista philippensis occurs throughout peninsular India, the small Travancore flying squirrel Petinomys fuscocapillus fuscocapillus is restricted to the Western Ghats (Prater, 1993). The distribution of this species is poorly known but our sightings were only in wet and humid forests at $60-200 \mathrm{~m}$ altitude on the western slopes of Brahmagiri-Makut. Previously the species has been seen in coconut groves of coastal Kerala (Kurup, 1989) and in the Indira Gandhi Wildlife Sanctuary in Tamil Nadu. The encounter rate of the Travancore flying squirrel indicates that there is probably a relatively healthy population of this species in Brahmagiri-Makut.

Table 4 Summary of the information obtained from interviews (Appendix 1; see text for details) about hunting practices in Brahmagiri-Makut and Sirsi-Honnavara.

\begin{tabular}{|c|c|c|}
\hline Practice & Brahmagiri-Makut & Sirsi-Honnavara \\
\hline $\begin{array}{l}\text { Licenced guns with the predominant } \\
\text { community (Source: Police Department) }\end{array}$ & $\begin{array}{l}\text { Owned by } 91 \% \text { of familes (Kodava families } \\
\text { on eastern border) }\end{array}$ & Data not available \\
\hline Unlicenced guns (Source: Forest Department) & $\begin{array}{l}\text { Owned by } 65 \% \text { of families in four villages } \\
\text { in Kerala on the western border }\end{array}$ & Data not available \\
\hline Locally made guns (Source: Interviews) & Few & Many \\
\hline Guns used for hunting & Mainly personal guns & Borrowed \& also personal \\
\hline Traps found & 2 & 37 \\
\hline Hunting strategy & Guns, rarely traps & Traps \& guns \\
\hline Mammals hunted & Mainly large mammals & Mainly small mammals \\
\hline $\begin{array}{l}\text { Encounters with hunters during this } \\
\text { study (daytime) }\end{array}$ & 7 & 0 \\
\hline Hunting time & Mainly daytime & Mainly night-time \\
\hline Hunting purpose & $\begin{array}{l}\text { Mainly commercial (sale of meat \& for } \\
\text { medicinal use); also for personal } \\
\text { consumption \& crop protection }\end{array}$ & $\begin{array}{l}\text { For personal consumption \& crop } \\
\text { protection }\end{array}$ \\
\hline Species hunted for commercial purposes & Primates, gaur, pig, sambar & None \\
\hline Religious inhibitions against hunting & None & $\begin{array}{l}\text { Strong for primates; selective within } \\
\text { certain communities or castes }\end{array}$ \\
\hline
\end{tabular}


The discovery of this new locality for this little known species significantly enhances prospects for its conservation, and further surveys need to be carried out in the low altitude forests on the western slopes of the Western Ghats in the states of Kerala and Karnataka.

Although a small population of elephants was formerly present in Sirsi-Honnavara (Nair \& Gadgil, 1978), it has now completely disappeared (Kumara \& Singh, in press) and there are no areas nearby that harbour elephants. Brahmagiri-Makut is close to large belts of deciduous forests of Nagarahole National Park, which harbours a large population of elephants, and there is frequent movement of elephants between the two areas (Nath \& Sukumar, 1998).

In areas relatively free of human interference the distribution and abundance of mammal species can be explained largely in terms of ecological variables. However, in human dominated landscapes, such as those of Brahmagiri-Makut and Sirsi-Honnavara, species richness and abundance are significantly influenced by anthropogenic factors. In this context one of our most important findings was the effect of hunting practices and belief systems on the relative abundance of mammals, with larger, diurnal mammals being more common in Sirsi-Honnavara and smaller, nocturnal mammals being generally more common in Brahmagiri-Makut. In the latter area the predominant communities of Kodavas, Muslims and Christians are active hunters and do not have religious inhibitions against hunting any particular species. Kodavas have been accorded the right, dating from the British colonial period, to own licenced guns. On the western border of Brahmagiri-Makut mammals are hunted both for consumption and for sale of their meat. The subsistence communities of Sirsi-Honnavara farm smallholdings in the forests. Most of the guns in this area are unlicenced and traps are widely used for hunting. Being predominantly Hindus, these communities accord a holy status to primates and do not hunt them; hunting is for personal consumption only.

In Brahmagiri-Makut indiscriminate daytime hunting using guns would have the greatest impact on large diurnal mammals as they are easily sighted, whereas in SirsiHonnavara night-time hunting with traps and avoidance of certain species such as primates would affect small mammals more than large mammals. Apart from the distribution pattern of the Nilgiri langur and elephants the two areas are otherwise largely comparable in habitat structure and in the composition of mammals. The difference in the relative densities of large and small mammals between the two areas is probably due to the differences in religious beliefs and hunting practices.

Karanth (1985) estimated that there were 10 groups of the Endangered lion-tailed macaque in BrahmagiriMakut, whereas 18 years later we were only able to locate one surviving group. The Brahmagiri-Makut ecotone is one of the few areas in the Western Ghats where all of the primate species of southern India can still be found, but the area does not receive any official protection. In SirsiHonnavara encroachment of agriculture into the forest is a regular practice, and the remaining forests, although contiguous, now exist only as a network of narrow strips. The forest is in danger of being fragmented, as has happened in the Anaimalai Hill ranges of the southern Western Ghats (Umapathy \& Kumar, 2000; Singh et al., 2002). Many of the mammals of this area will then be isolated in small forest fragments.

\section{Acknowledgements}

This study was sponsored by the Department of Science and Technology, Government of India (Grant No. SP/ SO/C-16/99) to Mewa Singh. We thank the Chief Wildlife Warden and the officials of the Karnataka Forest Department for permission to carry out this study and for assistance in the field. We acknowledge the support of Mridula Singh, M.S. Chaitra,. Shantala Kumar, B.K. Sharat, K.M. Chinnappa, A.K. Sharma and M. Anand Kumar.

\section{References}

Arita, H.T., Robinson, J.G. \& Redford, K.H. (1990) Rarity in Neotropical forest mammals and its ecological correlates. Conservation Biology, 4, 181-192.

Ashraf, N.V.K., Kumar, A. \& Johnsingh, A.J.T. (1993) On the relative abundance of two sympatric squirrels of Western Ghats, India. Journal of the Bombay Natural History Society, 90, 158-162.

Ashraf, N.V.K., Kumar, A. \& Johnsingh, A.J.T. (1995) A survey of two endemic civets of the Western Ghats: the Malabar civet (Viverra civettina) and the brown palm civet (Paradoxurus jerdoni). Oryx, 27, 109-114.

Cincotta, R.P., Wisnewski, J. \& Engelman, R. (2000) Human population in the biodiversity hotspots. Nature, 404, 990-992.

Diamond, J.M. (1989) Overview of recent extinctions. In Conservation for the Twenty-First Century (eds D. Western \& M. Pearl), pp. 37-41. Oxford University Press, New York, USA.

IUCN (2003) 2003 IUCN Red List of Threatened Species. IUCN, Gland, Switzerland [http:/ / www.redlist.org, accessed 20 May 2004]

Johnsingh, A.J.T. (1986) Diversity and conservation of carnivorous mammals in India. Proceedings of the Indian Academy of the Sciences, Supplement, 73-89.

Karanth, K.U. (1985) Ecological status of the lion-tailed macaque and its rainforest habitats in Karnataka, India. Primate Conservation, 6, 73-84.

Karanth, K.U. (1986) Status of wildlife and habitats in Karnataka. Journal of the Bombay Natural History Society, 83, 166-179.

Kemper, C. (1988) The mammals of Pasoh Forest Reserve, Peninsular Malaysia. Malaysian Natural Journal, 42, 1-19. 
Kumar, A., Umapathy, G. \& Prabhakar, A. (1995) A study on the management and conservation of the small mammals in fragment rainforests of Western Ghats, South India: a preliminary report. Primate Conservation, 16, 53-58.

Kumar, M.A., Singh, M., Srivastava, S.K., Udhayan, A., Kumara, H.N. \& Sharma, A.K. (2002) Distribution patterns, relative abundance and management of mammals in Indira Gandhi Wildlife Sanctuary, Tamil Nadu, India. Journal of the Bombay Natural History Society, 99, 184-210.

Kumara, H.N. \& Singh, M. (in press) Disappearance of elephants in Uttara Kannada. Journal of the Bombay Natural History Society.

Kurup, G.U. (1989) Rediscovery of the small Travancore flying squirrel. Oryx, 23, 2-3.

Madhusudan, M.D. \& Karanth, K.U. (2002) Local hunting and the conservation of large mammals in India. Ambio, 31, 49-54.

Mudappa, D. (2001) Ecology of the brown palm civet Paradoxurus jerdoni in the tropical rainforests of the Western Ghats, India. $\mathrm{PhD}$ thesis, Bharathiar University, Coimbatore, India.

Myers, N., Mittermeier, R.A., Mittermeier, C.G., da Fonseca, G.A.B. \& Kent, J. (2000) Biodiversity hotspots for conservation priorities. Nature, 403, 853-858.

Nair, P.V. \& Gadgil, M. (1978) The status and distribution of the elephant population of Karnataka. Journal of the Bombay Natural History Society, 75, 1000-1016.

Nath, C. \& Sukumar, R. (1998) Elephant-Human Conflict in Kodagu, Southern India: Distribution Patterns, People's Perceptions and Mitigation Methods. Asian Elephant Conservation Centre, Bangalore, India.

Pascal, J.P. (1988) Wet Evergreen Forests of the Western Ghats of India. Institute Francais de Pondicherry, Pondicherry, India.

Pimm, S. \& Raven, P. (2000) Extinction by numbers. Nature, 403, 843-845.

Prasad, S.N., Nair, V.P., Sharathchandra, H.C. \& Gadgil, M. (1978) On factors governing the distribution of wild mammals in Karnataka. Journal of Bombay Natural History Society, 75, 718-743.

Prater, S.H. (1993) The Book of Indian Animals. 4th Impression. Bombay Natural History Society, Bombay, India.

Rai, N.D. \& Kumar, A. (1993) A pilot study on the conservation of the Malabar civet, Viverra civettina (Blyth, 1862): project report. Small Carnivore Conservation, 9, 3-7.

Ramachandran, K.K. \& Joseph, G. (2001) Distribution and demography of diurnal primates in Silent Valley National Park and adjacent areas, Kerala, India. Journal of the Bombay Natural History Society, 98, 191-196.
Ramesh, B.R. (2001) Patterns of vegetation, biodiversity and endemism in the Western Ghats. Memoir Geological Society of India , 47, 973-981.

Robinson, J.G. \& Redford, K.H. (1986) Body size, diet and population density of Neotropical forest mammals. The American Naturalist, 128, 665-680.

Singh, M., Singh, M., Kumara, H.N., Kumar, M.A. \& d'Souza, L. (1997) Inter- and intra-specific associations of non-human primates in Anaimalai Hills, South India. Mammalia, 61, $17-28$.

Singh, M., Singh, M., Kumar, M.A., Kumara, H.N., Sharma, A.K. \& Kaumanns, W. (2002) Distribution, population structure and conservation of lion-tailed macaques (Macaca silenus) in the Anaimalai Hills, Western Ghats, India. American Journal of Primatology, 57, 91-102.

Umapathy, G. \& Kumar, A. (2000) The occurrence of arboreal mammals in rainforest fragments in the Anamalai Hills, South India. Biological Conservation, 92, 311-319.

Yoganand, T.R.K. \& Kumar, A. (1995) The distribution of small carnivores in the Nilgiri Biosphere Reserve, southern India: a preliminary report. Small Carnivore Conservation, 13, 1-2.

\section{Appendix}

The appendices for this article are available online at http:/ /journals.cambridge.org

\section{Biographical sketches}

H.N. Kumara is studying the ecology and distribution patterns of mammals in the state of Karnataka. He has previously worked on the behaviour of non-human primates in the Western Ghats and his interests also include the conservation of threatened species.

Mewa Singh has been working on the ecology and behaviour of mammals, especially of non-human primates, for nearly three decades. He has worked on eight species of primates, mostly in their wild habitats. His primary interest is to apply behavioural data for the conservation and management of mammals, and thereby bridge the gap between behavioural and conservation biology. 